\begin{tabular}{lr} 
SOSVOrnal of sociologicalcontext & ISSN: $2757-5942$ \\
2020,1(1), 13-26 \\
\hline Çevrimiçi Basım / Online Publication: 28.12 .2020 & https://doi.org/10.52108/2757-5942.1.1.2 \\
Derleme Makalesi/Review Article & Gelis Tarihi/Received: 20.12 .2020 \\
Kabul Tarihi/Accepted: 27.12 .2020
\end{tabular}

\title{
Pierre Bourdieu Sosyolojisi ve Spor Alanının İnşası
}

\section{Sociology of Pierre Bourdieu and Construction of Sports Field}

\author{
Birtan BOZLU* \\ (D) 0000-0002-8435-6842
}

\begin{abstract}
Öz
Spor ya da spor yapma pratiği insanlık tarihiyle hemen hemen paralel bir çizgide ilerlemiş ve aynı şekilde insanlıkla paralel bir gelişim göstermiştir. Her daim artan bir ilgiyle toplumsal yaşamda yer bulan spor alanı zamanla bilim alanını da meşgul etmeye başlamıştır. 1900'lü yılların ortalarından itibaren sosyoloji biliminin bir alt alanı haline gelen spor alanı pek çok isim tarafından çeşitli metodolojik ve teorik açılardan ele alınmıştır. 1980'li yıllardan itibaren, spor sosyolojisi alanında sosyolojik perspektifinden faydalanılan önemli isimlerden biri de Pierre Bourdieu olmuştur. Özellikle onun teorik perspektifini tek bir çerçevede toplayarak ortaya koyduğu "oyun metaforu" sporun toplumsallığıyla ciddi bir paralellik göstermektedir. Spor sosyolojisi ve elbette sporun toplumsallığı hakkında konuşabilmek için alanın inşa süreçleri, tarihselliği ve özerkliğine yapılacak olan vurgulara dikkat çeken Bourdieu'nun eylem teorisinin sacayaklarını oluşturan alan, habitus ve sermaye kavramları da spor alanının toplumsal uzamda nasıl inşa edildiğini, hangi ilișki ağlarıyla var olduğunu ortaya koyabilmek adına sıklıkla spor alanında faaliyet gösteren araștırmacılar tarafından çalışmalarda kullanılmıștır. Bu nedenle çalıșmada, spor sosyolojisinin gelișim süreçleri, Bourdieu'nun teorik çerçevesinin spor sosyolojisi için sunduğu imkanlara, Bourdieu'nun spor sosyolojisi üzerine yaptığı açıklamalara ve spor alanının toplumsal uzamda nasıl inșa edilebileceği üzerine yorumlara yer verilmiștir.
\end{abstract}

Anahtar Kelimeler: Spor Sosyolojisi, Bourdieu, Alan, Habitus, Sermaye

\begin{abstract}
Sports or the practice of sporting have progressed in parallel with the history of humanity, just as they have developed in parallel with humanity. The sports field, which has a growing interest in social life, has started to occupy the field of social science in time. Since the mid-1900s, sports have become a sub-field of sociology and been discussed in various methodological and theoretical aspects by many people. Especially since the 1980s, Pierre Bourdieu has been one of the important figures whose sociological perspective is utilized in the field of sports sociology. Especially, the "metaphor of playing" that he put forward by gathering his theoretical perspective in one frame shows a serious parallelism with the sociality of sports. Bourdieu's concepts of field, habitus and capital, which constitute the trivet of the theory of action and draws attention to the emphasis on the construction processes, historicity and autonomy of the field are frequently used in studies by researchers working in the field of sports in order to reveal how the sports field is built in social space and with which network of relationships it exists. For this reason, the development processes, the possibilities of Bourdieu's theoretical framework for, and Bourdieu's explanations on the sociology of sports, and how to build a sports field in a social space are discussed.
\end{abstract}

Keywords: Sociology of Sports, Bourdieu, Habitus, Field, Capital

\footnotetext{
*Arş. Gör., Akdeniz Üniversitesi Edebiyat Fakültesi Sosyoloji Bölümü. 凶 birtanbozlu@akdeniz.edu.tr
} 


\section{Giriş}

İnsanlığın varoluşuyla neredeyse paralel bir şekilde ortaya çıkan ve insanlık tarihiyle birlikte değişip şekillenerek günümüze kadar gelen bir faaliyet olan spor ya da spor yapma eylemi toplumsal yaşamın her zaman bir parçası olagelmiştir. Toplumsal yaşamla her daim iç içe bir görüntü çizmesine ve gündelik pratikler içerisinde önemli sayılabilecek bir yer kaplamasına rağmen sporun sosyoloji ya da daha genelde sosyal bilim disiplini içerisinde görece geç yer bulduğu söylenebilir. Ancak, spor alanı sosyal bilimler alanında bir alt disiplin olarak ortaya çıktığı dönemin ardından birçok sosyal bilimci tarafından dönemin hâkim teorik perspektifleri ve analiz yöntemleri üzerinden makro ve mikro düzeyde araştırmalara konu olmuş ve spor-toplum ilişkisi üzerinden çok sayıda sosyolojik bilgi ve çlkarımlar üretilmiştir.

Spor alanının sosyolojik araştırma pratiğinde klasik ve çağdaş döneme ait pek çok teorik perspektifin kullanılmaya başlanmasıyla birlikte, spor sosyolojisi alanında öne çıkan teorik ve kavramsal çerçevelerin sahiplerinden biri de Pierre Bourdieu ve onun sosyal bilim anlayışı olmuştur. Bu nedenle, bu çalışmada spor sosyolojisi alanındaki tarihsel ve teorik açıdan gelişim süreçleri de göz önüne alınarak, Bourdieu sosyolojisinin spor alanında nasıl tezahür ettiği, teorik ve kavramsal çerçevesinin alan içerisinde nasıl kullanıldığı ve analiz edildiği çeşitli spor sosyolojisi çalışmalarından da örnekler sunularak ön plana çıkarılmaya ve açıklanmaya çalışılmıştır. Bu eksende, çalışmada ilk olarak spor alanının tarihsel süreç içerisinde toplumsal alanda sürekli artan önemi ve karmaşıklaşan yapısına, akabinde bu artan önem ve alanın derinleşen ilişki ağları doğrultusunda spor sosyolojisinin geçirdiği tarihsel süreçlere değinilmiştir. Ardından Pierre Bourdieu'nun ortaya koyduğu kavramsal çerçevenin alt başlıklarla spor alanı içerisinde ifade ettiği anlam ve sunduğu imkanlar çeşitli çalışmalardan örneklerle belirtilmiş ve son olarak Bourdieu'nun sosyal bilim alanında ortaya koyduğu kavramsal çerçeve ve bu kavramsal çerçeve üzerinden spor alanında üretilen çalışmaların analizinde nasıl bir gidiş yolu izlenebileceği ve bir spor sosyolojisi çalışmasının Bourdieu perspektifinden nasıl olması gerektiği aktarılmaya çalışılmıştır.

\section{Spor-Toplum İliş̧kisi ve Spor Sosyolojisinin Doğuşu}

Tarihsel süreç içerisinde karşılaşılan en eski spor dalları, o dönemde yaşayan insan topluluklarının gündelik gereksinimleri ve kültürel pratikleri üzerine geliștirilmiş ve avlanma, savaşma, hayatta kalma gibi gündelik ve hayati faaliyetlerin bir provası olarak görülebilecek fiziksel aktivitelerden (ya da oyunlardan) oluşmaktadır (Dever, 2010: 29). Dönemin insanlarının doğa karşısında verdikleri hayatta kalma mücadelesiyle ilişkili bir şekilde ortaya çıkan ve bu mücadelenin bir provası ya da bir ön hazırlı̆̆ı şeklinde gerçekleştirilen bu fiziksel faaliyetler (Fişek, 1985: 8-9), aynı zamanda dini ya da ruhani bir nitelik taşıma özelliğine de sahipti (Delaney ve Madigan, 2015: 50). Günümüzde gerçekleştirilen modern sportif aktivitelere ve spor yapma mantığına kısmen yakın, tarihin ilk örgütlü ve belirli bir düzen içinde gerçekleștirilen spor organizasyonu ise M.Ö. 776 yllında başlayan ve M.S. 393 yılında belirli bir dönem için yasaklanmasına rağmen düzenli olarak 4 yılda bir (belirli bir süre için 8 yılda bir) gerçekleştirilerek günümüz kadar devamlılığını koruyan Olimpiyat Oyunları olmuştur (Fişek, 1985: 12). Modern ve örgütlü spor dallarının büyük çoğunluğuna öncülük etmiş olan antik dönem Olimpiyat oyunları, günümüzde gerçekleştirilen spor organizasyonlarına görece yakın sayılabilecek bir sportif faaliyet biçimi olmakla birlikte, ilk ilkel oyun ve spor aktivitelerine benzer şekilde dini değerlere hizmet etmiş ve sporculara sunulan ödül ve itibar da maddiyattan uzak manevi ya da dini açıdan değere sahip ödüller olmuştur (Young, 2004: 12-23). Bu açıdan, antik olimpiyatların hem günümüz sporlarına olan benzerliğinden kaynaklı olarak bir çıkış noktası sayılabilecek nitelikte örgütlü yapısı hem de daha eski dönem anlayışının görece devam etmesinden dolayı modern spora doğru giden süreçte önemli bir köprü görevi gördüğü söylenebilir. Antik Yunanda soylu bir faaliyet ya da egemen kitlenin uğraşı (egemen uğraş ayrıca "erkek" egemen bir uğraş şeklinde de ifade edilebilir) olarak öne çıkan sportif aktiviteler, Roma İmparatorluğu dönemiyle birlikte üst tabakanın izleyici, köle toplumunun ise eyleyici, yani spora direk katılımcı olduğu etkinliklere dönüșmüştür (Talimciler, 2015: 23-24). Roma İmparatorluğunun çöküşünden başlayıp 18. Yüzylla kadar devam eden süreç boyunca sportif faaliyetler, sporcu olma mantığı ve sporun uygulanış biçimi bazı 
rastlantısal değişimler ve ufak tefek çeşitlenmeler dışında ciddi bir dönüşüm ya da ilerleme kaydetmemiştir (Collins, 2013: 2). Ancak 18. Yüzyılda yaşanan toplumsal olay ve dönüşümlerle birlikte spor-toplum ilişkisinin seyri ve elbette toplumsal hayat içerisindeki önemi de ciddi biçimde değişmeye başlamıştır.

18. yüzyılla birlikte İngiltere'de, sanayi devrimi ekseninde önemli toplumsal değişimler yaşandı ve bu değişimler aynı șekilde sportif aktiviteleri, sporun ve spor yapma pratiğinin anlamını da kökten değiştirmiştir. Başta İngiltere olmak üzere, 18. Yüzyılla birlikte Avrupa'da sportif organizasyonlar sadece birer boş zaman aktivitesi olmanın ötesine geçirilerek, genelleştirilmiş kurallara, sistematik ve düzenli bir işleyişe sahip organizasyonlara dönüşmeye başlamıştır. Sanayi devriminin meydana getirdiği ekonomik, toplumsal ve siyasal değişim, ayrıca bu dönem içerisinde kapsamlı iş bölümü ekseninde artan boş zaman, sporun geniş kitlelere ulaşmasında ve yaygınlaşmasında ciddi bir etkiye sahip olmuştur. Sporun metalaştırılarak ve seyirlik bir gösteri haline getirilerek yarattı̆̆ ticari firsatlar, özellikle toplumun üst kesiminin bu alana bir kar kapısı olarak bakmasına ve sporun profesyonelleşmeyle birlikte bir meslek haline dönüşmesine neden olmuş ve bireyin gündelik hayatında artan boş zaman sporun geniş kitlelere ulaşması kolaylaşmıştır (Talimciler, 2015: 28-29). Kapitalizmin yükselişe geçtiği bu dönemde sportif faaliyetler ve sporcular metalaștırılarak, bir eğlence endüstrisi ve para kazanma amacı taşımaya başlamıştır. Sporun ticarileşmesi ve getiri sağlayan seyirlik malzemeye dönüşmesi de kapitalizm ve spor birlikteliğinin ekonomik ve ideolojik olarak ciddi şekilde genişlemeye başladığı bir dönem olmuştur. Elbette kapitalist anlayıșın ve spor organizasyonlarının metalaştırılmaya müsait olan yapısı, rekabet ve eğlencenin birlikteliği gibi önemli ortak noktaları spor dallarının genelleștirilmiş kurallarının, organize sportif yapıların, örgüt ve federasyonların ortaya çıkışında ve spor organizasyonlarının bu sayede geliștirilmesinde önemli bir pay sahibi olmuştur (Collins, 2013: 3-14).

Tarihsel süreç içerisinden aktarılan bu gelişmeler dikkate alındığında sportif aktivitelerin süreç içerisinde devamlı olarak büyüdüğü, çeşitlendiği ve toplumsal yaşamın çoğu noktasında kendini var ettiği söylenebilir. Bu nedenle, spor alanının pek çok noktası da sosyolojik açıdan ciddi bir öneme sahip olmakta ve spora doğrudan ya da dolaylı katılım, sportif alan içerisinde yaratılan kültür, spor alanının tarihsel devamlılığı, spora katılım gösteren insanların toplumsal hayattaki konumlanmaları ve ilişkileri gibi pek çok başlık spor alanı ve sosyoloji bilimi ekseninde ele alınmaktadır. Bu sebeple, spor alanının sosyoloji biliminin bir parçası ve toplumsal yaşamın ana hatlarından biri olduğu gerçeği de rahatllkla ifade edilebilmektedir.

Sosyal bilimlerde spor alanına yönelik akademik ve bilimsel çalışmalar, spor alanının toplumsal yaşamdaki önemini tarihsel süreç içerisinde lineer bir biçimde arttırmasıyla birlikte, ylllar içinde büyük ölçüde önem kazanmaya başlamıştır. 20. Yüzyıldan itibaren ilk adımların atılmaya başlandı̆̆ını söyleyebileceğimiz spor sosyolojisi alanı, kendini bir alt disiplin olarak meşrulaştırmak amacıyla hem spor dünyasında eğitim görmüş kişiler tarafından hem de bu alanla özdeşleşen isimler tarafından ortaya koyulan görüşler çerçevesinde büyük ölçüde kendini tanımlamaya başlamıştır (McPherson 1981: 10). Spor ve toplum arasındaki ilişkilere odaklanan, sosyolojinin bir alt disiplini şeklinde kısa bir ifadeyle tanımlayabileceğimiz spor sosyolojisi, spor alanında bireylerin ve çeşitli grupların davranışlarıyla ve sporun resmi ve gayri resmi örgütlenişi ve işleyişinde var olan kurallar ve süreçlerle doğrudan ilgilenmektedir. Sosyal bilimciler tarafından spor kurumu içerisinde bulunan süreçlere ve bu toplumsal etkenlerin insan davranışları ile olan ilişkilerine odaklanıldığı bu alt alanı araştırmacılar, spor kurumlarında deneyimlenen süreçleri, kalıpları, sorunları, değerleri ve davranışları sistematik bir şekilde çeşitli teorik perspektiflerle tanımladıkları bir alan olarak özetlemektedirler (Delaney ve Madigan, 2015: 8).

Spor alanı üzerine sosyolojik ya da kısmen sosyolojik olarak nitelendirebileceğimiz çalışmalar esasında üç yüz yıl öncesine kadar dayandırılabilir. Bu çalışmaların çok büyük çoğunluğu sosyolojik eserler olarak tanımlanmamakla birlikte, spor alanı üzerine sosyal bilim perspektifinde çalışma yürüten araştırmacılar için son derece değerli ve ilginç açıklamalar barındırmaktaydı (Yiannakis, Melnick ve Morgan, 2019). 18. Yüzyıldan 19. Yüzyıla kadar olan yaklaşık bir asırlık süreçte de 
özellikle İngiltere'de, spor alanının açıklanmasına ve anlaşılmasına yönelik birtakım akademik gelişmeler yaşanmıştır. Bu dönemde, içerisinde spor alanına az ya da çok yer veren çalışmalar (Risse,1921; Huizinga,1938; Horkheimer ve Adorno, 1947) çoğunlukla akademik kurumlar tarafından ortaya konmamasına rağmen daha sonra bir alt disiplin haline gelecek olan spor sosyolojisi alanında faaliyet gösteren araştırmacılar için önemli referans noktaları olmuştur. 20. Yüzyılın ortalarına kadar kurumsallaşmaktan uzak olan spor sosyoloji, 1900'lü yıllarından başlarında yayınlanan spor üzerine çeşitli metinlerin ardından yaklaşık 30 yllık bir duraklama evresine girmiş. Ancak, 1950'li yllardan itibaren sistematik bir alt alan olma yolunda ciddi bir yapılandırılmaya tabi tutulmuștur (Souza 2010, 47-48).

Bir disiplin olarak, spor sosyolojisi yaklaşılk olarak 60 yıldır varlığını sürdürmektedir. Spor sosyolojisi üzerine ortaya koyulan ilk çalışma pek çok isim tarafından Heinz Risse'nin Spor Sosyolojisi (Soziologie des Sports) çalışması olarak gösterilmekle birlikte, organize olma ve kurumsallaşma açısından ilk spor sosyologlarını göz önüne aldığımızda, çoğu isim resmi bir başlangıç noktası olarak Gerald Kenyon ve John Loy'un 1965 tarihli "Toward a Sociology of Sport" (Spor Sosyolojisine Doğru) ve Harry Edwards'ın 1973'deki "Sociology of sport (Spor Sosyolojisi) çalışmalarını işaret etmektedir. 1965 yılında Kenyon ve Loy spor sosyolojisi üzerine yaptıkları ilk çalışmada, sporun artık toplumsal yaşamda çok büyük ve karmaşık kültürel bir fenomen haline geldiğini ve görmezden gelinmemesi gereken toplumsal bir kuruma dönüştüğünü ifade etmiştir. Ayrıca, toplumların spor faaliyetlerine olan düşkünlüğüne rağmen, sosyal bilimler alanında bir olgu olarak sporun hemen hiç ciddiye alınmayan bir alan olarak âtıl bırakıldığını ve sporun toplumsal yaşamda ve sosyal bilimlerde israrla görmezden gelindiğini (ya da çok az değer verildiğini) ifade etmişlerdir (Delaney ve Madigan, 2015: 6). Ancak 20. Yüzyılın ikinci yarısından itibaren spor olgusunun toplumsal yaşamdaki etkinliğinin artması ile bu alanda üretilen çalışmalar da hiz kazanmaya başlamıştır. Bu dönemden itibaren hem spor alanının farklı noktalarında sosyal bilimciler tarafindan araștırmaların boyutu genișlemiș hem de sosyoloji alanında hâkim teorik perspektiflerle farklı şekillerde spor alanını ele almaya başlamışlardır.

Burada açıklanması faydalı olabilecek nokta, özellikle spor sosyolojisinin ilk yıllarından itibaren bu alanı anlamak ve açıklamak adına kullanılan sosyolojik teorilerin spor olgusuna bakış açısını ortaya koymak olacaktır. Çünkü, klasik sosyolojik teorilerin üç temel direği olarak ifade edebileceğimiz işlevsel, çatışmacı ve sembolik etkileşimci teoriler spor sosyolojisi alanında üretilen ilk çalışmalarda sıklıkla (neredeyse istisnasız şekilde) başvurulan teoriler olarak karşımıza çıkmaktadır.

Spor sosyolojisi alanında ortaya koyulan ilk çalışmalar dönemin hâkim teorik yaklaşımlarından biri olmasının da etkisiyle işlevselci yaklaşımların sayıltıları üzerinden ortaya koyulmuştur (bkz. Kenyon \& Loy, Toward a Sociology of Sport, 1965). Toplumsal alanı makro düzeyde ele almaya meyilli ve toplumu çoğunlukla failler üstü olarak kabul eden işlevsel teori çerçevesinde spor alanı, toplumsal bir kurum olarak çeşitli işlevlere sahip ve toplumsal alanı meydana getiren diğer kurumlarla etkileşim içerisinde düzene hizmet eden bir mantıkla ele alınmıştır. İşlevselci teorisyenler tarafından spor alanı büyük oranda olumlu işlevleri olduğu kabulü üzerinden makro bir bakış açısıyla ele alınmış ve toplumsal yașamda spor kurumunun devamlılığını mümkün kılan işlevleri üzerinden değerlendirilmiștir (Loy \& Booth, 2000: 14-15).

Çatışma kuramcıları ise, işlevsel teorilerin makro perspektiflerinden kopmamakla birlikte, spor alanını ele alırken Marksist geleneğe paralel olarak sporu sadece bir düzen ve devamlılık anlayışıyla değil, bir muhalefet ya da direniş ortamı olarak ifade ettiği gibi geri döndürülemez ölçüde kapitalist, sömürüye müsait, ideolojik ve politik olarak suiistimal edilebilecek bir alan olarak da ifade etmektedir. Çatışmacı ya da Marksist bir spor sosyolojisinin temel özelliği, kültürlerin, kurumların ve uygulamaların yorumlanması ve dönüşümünün diyalektiği üzerine kurulmaktadır. Çatışmacı bir spor sosyolojisi anlayışının yörüngesi bu açıdan, tarihsel gelişimi ve dönüşümleri ön plana koyan, sınıfsal ilişkilerin spor alanındaki tezahürünü ve kapitalist dünyada güç-iktidar ve mücadele gibi kavramlar üzerinden ilerlediği ifade edilebilir (Talimciler, 2015: 85). 
Sembolik etkileşimci teoriler ise spor alanında sınırlı ya da mikro perspektifler ve öznel niş olaylar üzerinden bir spor sosyolojisi imkânı sunmaktadır. Daha çok sembolik anlamlar, ilişkiler ve spor alanı içerisindeki mikro boyutlar üzerine bir analizi amaç edinmiş olan bu tarz kuramlar ayrıca etnografi ve etnometodoloji gibi mikro ve "mid-range" analizlerin spor alanında mümkün kılınabilmesinin de önünü açmıştır (Donnelly 200, 78-79).

Spor sosyolojisinin bir alt disiplin olarak var edilmeye başlandığı ilk dönemlerde, bahsettiğimiz bu üç klasik sosyolojik yaklaşım ciddi bir öneme sahip olmuştur. Ancak özellikle işlevselci teoriler ilk spor sosyolojisi çalışmalarında oldukça etkin kullanılmış ve spor alanı bir düzen, fayda ve sistem devamlılı̆ı konseptleri üzerinden ele alınarak değerlendirilmiştir. Diğer yandan, spor sosyologlarının işlevselci paradigmaya sıkı sıkıya bir bağllık göstermeleri, çatışmacı ve eleştirel perspektiflerin de bu alanda farklı bir bakış açısıyla ortaya çıkmasına yol açmıştır. Ancak, çatışmacıeleştirel yaklaşımlar üzerinden üretilen spor sosyolojisi çalışmalarının çoğu ilk etapta bu yaklaşımların göstergelerinden uzak kalmış ve işlevselci-muhafazakâr bir anlayışla süregelmeye devam etmiştir. Bu durum, spor sosyolojisi alanında çalışmalar yapan isimlerin kendilerini kavramsal ve metodolojik pek çok sorunla boğuşurken bulmalarına neden olmuştur. Burada belirtilmesi gereken nokta, 1960 ve 1970 yıllarını kapsayan süreçteki dönemin sosyal bilim tartışmalarına paralel olarak, sadece spor sosyolojisi alanında değil, bütün alt alanlarda kavramsal ve metodolojik çıkmazların ve tartışmaların yoğun olduğu bir döneme tekabül ediyor olmasıydı. 1960'lı yıllardan başlayıp 1970'li yıllara kadar devam eden süreçte, küresel çapta etkin savaşlar, özellikle ABD'de baş gösteren toplumsal eşitsizlikler, ırkçı uygulamalar ve kamusal huzursuzluk, sosyal bilimler alanında toplumsal yaşamı anlama ve açıklama konusunda önemli tartışmalar ve arayışlara neden olmuş ve spor sosyolojisi dahil olmak üzere sosyal bilim dallarının neredeyse hepsinde bir "paradigma savașı" ortaya çıkmasına neden olmuştur (Yiannakis, Melnick ve Morgan 2019).

1970'li yıllardan itibaren spor sosyolojisi alanında, başta işlevselcilik yanlıları olmak üzere, Marxistler, sembolik etkileşimciler, feminist teorisyenler ve kültürel çalışmaları savunan isimler spor sosyolojisi alanının teorik ve kavramsal boyutlarını temellendirmek amacıyla ciddi tartışmalar içerisine girmişlerdir. Spor sosyolojisi alanında ortaya çıkan bu teorik tartışmalar özellikle bu alt alanın ilk isimleri ve yeni-ikinci kuşak olarak gösterebilecek isimler arasında şekillenmekteydi (Yiannakis, Melnick ve Morgan 2019). Bu iki tarafın isimlerinin ve bakış açısının genel olarak açıklanması gerekirse, spor alanında istatistikler üzerinden nicel araştırmaların önemine vurgu yapan ve işlevselciliğin destekçileri konumundaki Loy, Kenyon ve Edwards gibi spor sosyolojisi alanının ilk isimleri bir tarafta yer alırken, salt işlevselci yaklașıma senkronik olmaktan uzak, ikilikleri yeniden üreten bir anlayışta olmasından dolayı mesafeli yaklaşan ve daha bütüncül bir teorik perspektifi savunan Elias, Dunning, Peter Mcintosh ve elbette Pierre Bourdieu sosyolojisinin savunucuları yer almaktadır (Souza 2010, 53).

Spor alanında üretilen çalışmaların analizlerinde kullanılan ve günümüzde gerçekleștirilen pek çok çalışmada teorik çerçevesine sıklıkla başvurulan isimlerden birisi de bu nedenle Fransız sosyal bilimci Pierre Bourdieu ve onun sosyal bilim anlayışıdır. Kendisini bir spor sosyoloğu olarak tanımasak ve sadece spor sosyolojisi alt disiplinine özgü bir çalışma üretmemiş olsa da Pierre Bourdieu spor sosyolojisi alanında açıklamaları ve teorik perspektifiyle sıklıkla karşımıza çıktığı gibi, spor alanının toplumsal yaşamdaki yeri, ayakları yere basan bir spor sosyolojisi çalışmasının nasıl olması gerektiği konularında önemli açıklamalarda bulunmuş ve bazı önemli çalışmalarında (Ayrım, kültür vs.) spor alanı üzerinden onun sosyolojisinin daha anlaşılabilir kılan dikkate değer örnekler ve açıklamalar sunmuştur.

\section{Bourdieu Sosyolojisi ve Spor Alanı Üzerine Açıklamalar}

Kendisi de eski bir rugby oyuncusu olarak bir sporcu geçmişine sahip olan Pierre Bourdieu, katıldığı konuşmalarda spor alanı ve spor sosyolojisinin mantığı üzerine açılamalarda bulunmuş, birçok çalışmasında da spor üzerinden örneklere yer vermiş̧tir. Yukarıda da bahsedildiği gibi, bir spor 
sosyoloğu olmamakla birlikte, belki de sporcu geçmişi ve spora toplumsal uzamda verdiği önemden dolayı teorisi ile bağlantılı olarak, bu konuyla ilgili birçok tespite ve açıklamaya çalışmalarında ve çeşitli konferanslarda yer vermiștir. Bu noktada, Bourdieu'nun spor alanı ve spor sosyolojisi hakkındaki açıklamalarına geçmeden önce, onun ortaya koyduğu kavramları, özellikle spor alanıyla olan ilişkisi üzerinden açılamak önem arz etmektedir.

Bütüncül bir toplum kuramına sahip olmakla birlikte, toplumsal gruplar arasındaki ilişkileri ve bu ilişkilerin nasıl yeniden üretildiğinin yanı sıra, bireylerin geçmişleri, beğeni yargıları ve pratikleri arasındaki bağlantıyı özgün olarak nitelendirebileceğimiz bir anlayışla ele almayı hedefleyen Pierre Bourdieu'nun sosyolojiye yaklaşımının temelini sosyal bilim alanını klasik dönemden beri meşgul eden birey-toplum çıkmazına çözüm yolları bulmak ve nesnellik-öznellik ikililiğini aşma çabası oluşturmaktadır (Tatlıcan ve Çeğin, 2016: 306-307). Bireyin rasyonelliğine göndermede bulunan öznelcilik, sosyolojide üretilen bilginin temelinin bireylerin kendi dünya görüşlerinden ve deneyimlerinden oluştuğunu ileri sürerken, buna karşı konumlanan nesnelcilik ise toplumsal determinizmlere vurgu yaparak toplumun işleyişini açılayan ve bireylerin kavrayışının ötesinde olan nesnel toplumsal yapılara işaret etmektedir (Jourdain ve Naulin, 2016: 38). Bourdieu'ya göre hem öznelcilik hem de nesnelcilik toplumsal dünyayı anlama ve gerçeği ortaya çıkaracak bilgiyi üretme konusunda kısmen başarılıdır. Bu nedenle bu tarz bir ikililiğin çözümü daha uzlaşmacı ve birleştirici bir hedefle refleksif (düşünümsel) bir sosyoloji anlayıșı ile mümkün olabilir (Cuff vd., 2015: 357). Bourdieu'nun nesnelcilik ve öznelcilik arasındaki bu karşıtlığı aşma çabası iki metodolojik düşünceyle sonuçlanmaktadır. İlk olarak, Bourdieu'nun araştırma mantığı 'katılımcı gözlem' olarak ifade edilen yönteme tekabül etmektedir. Katılımcı gözlemdeki amaç ise araştırmacının araştırma nesnesini nesnelleștirmesini mümkün kılmak ve gözlemlemeyi hedeflediği ilişkileri ve pratikleri odak noktasına yerleştirmesinin önünü açmaktır. İkinci olarak, araştırmacı ve araştırma nesnesi arasındaki ikililiği aşmayı hedeflemektedir. Araştırmacı araştırma sürecinde sadece nesnenin ya da nesne ile değil, kendi düșünce ve eylem pratiklerine karşı da eleștirel bir tutum sergilemek durumundadır (Baert, 1998: 30-31). Sosyolojik araştırma pratiği üzerine ortaya koyduğu düşüncelere paralel olarak, en başından beri aşmayı hedeflediği ikililikleri ve reddettiği tözcü anlayışı sıklıkla çalışmalarında da yansıtan Bourdieu, bu amaca uygun ve tutarlı bir kavramsal çerçeve ortaya koymuştur (Swartz, 2015: 137).

\subsection{Alan Kavramı ve Toplumsal Pratikler}

Bourdieu'nun eylem teorisinin sacayaklarından birini oluşturan alan (field), bünyesinde kazanılacak ve kaybedilecek şeyler barındıran, içerisinde yer alan faillerin devamlı olarak bu amaçla stratejiler üreterek mücadele içerisinde oldukları ilişkilerle kurutulan bir toplumsal çerçeveyi ifade etmek için kullanılır (Bourdieu, 2016b: 139). Bourdieu'ya göre toplumsal uzam, akademik alan, eğitim alanı, siyasi alan, spor alanı gibi birçok toplumsal alanın bir araya gelmesiyle oluşmaktadır. Toplumsal uzamı oluşturan çok sayıda alan bulunmakla birlikte, bütün toplumsal alanlar kendi sınırları içerisinde farklılaşan karakteristik niteliklere sahiptir. Bir alandan bahsedilebilmesi için, alan içerisinde eyleyicilerin uyması gerekli olan belirli kurallara, stratejiler üretilmesini mümkün kılan yatkınlıklara, ödül ve hedeflere gereksinim vardır (Bourdieu, 1997: 104). Bourdieu'nun alanın gereklilikleri üzerine yaptığı açıklama dikkate alındığında, spor'un toplumsal uzam çerçevesinde bir alan olup olmadığı çok daha açık bir hale gelmektedir. Bourdieu'ya kendi ifadesiyle sporu bir "mücadele alanı" olarak görmekte ve sporun toplumsal uzam içerisinde var olan bir alan olarak ifade etmektedir:
"Spor pratikleri alanı, başka şeylerin yanında, spor pratiğinin meşru tanımına ve spor faaliyetinin meșru işlevinin dayatılmasına ilișkin tekelin bir hedefolduğu mücadeleler alanıdır: profesyonelliğe karşı amatörlük, gösteri sporuna karşı faydacı spor, popüler -kitlesel- spora karşı bireysel -elit- spor vs. Bu alanın kendisi, meșru bedenin ve bu bedenin meșru kullanımının tanımı için verilen mücadelelerin alanına dahildir (...) (Bourdieu, 2015c, 103)."

David McGillivray ve Aaron McIntosh'un İskoçya Profesyonel Futbol Ligi alanında toplumsal pratikler üzerine ortaya koydukları 'Football is My Life': Theorizing Social Practice in the Scottish 
Professional Football Field ("Futbol Benim Hayatım": İskoç Profesyonel Futbol Alanındaki Toplumsal Pratikleri Kuramsallaştırmak) isimli çalışmalarında, futbol alanı ile ilgili Bourdieu'nun sporun toplumsal uzamın bir alt alanı olduğu yönündeki açıklamasına örnek olarak sunulabilecek ifadeler ortaya koymaktadırlar. McGillivray ve McIntosh'a göre, profesyonel futbol alanı içerisindeki toplumsal pozisyonlar belirlenmiş-somutlaştırılmış sermayeler ekseninde dağılmaktadır. Alan içerisindeki aktörlerin başarısı da bu sermayelere ulaşma ya da elde etme durumuna bağlıdır ve bu durum ayrıca alanın devamlılı̆̆ını da sağlamaktadır. Bununla birlikte futbol alanı, Bourdieu'nun da belirttiği üzere, hem dış etkenlerin (diğer alanların) baskılarına açıtıtır hem de kendi içerisinde her zaman çekişmeler (mücadeleler) barındırmaktadır (McGillivray ve McIntosh, 2006: 374-375). Bu eksende düşünüldüğünde, salt sporculardan değil, kendi içerisinde yapıları meydana getiren aktörler de barındıran spor olgusu belirli ilişki ağlarına sahip, değişken ve karmaşık bir içeriğe de sahiptir. Kendi özerk ve devamllığı süren bir tarihe sahip olan sporun ya da spor dallarının toplumsal yaşamda konumlanmış ve hem kendi içerisinde hem de dışsal alanda mücadele/çatışmayı mümkün hale getiren eyleyiciler barındıran, belirli tanımlara ve kurallara sahip karakteristik nitelikleri olan özerk bir alan konumunda olduğu da rahatllkla ifade edilebilir.

\subsection{Sermaye Türlerinin Değișkenliği}

Alan kavramı üzerine yapılan açıklamalarda bahsedildiği gibi, her alan kendine özgü karakteristik özelliklere, farklı ve değișebilir kurallara ve bireylere vadettiği ya da bireylerin çıkarları doğrultusunda sahip olmayı umduğu belirli konumlara ve ödüllere sahiptir. Bourdieu sermaye olarak isimlendirdiği nesnel ve nesnel olmayan bu ödülleri bulunduğu alanla ilişki içerisinde olan ve her bir formu alanın yapısına göre farklı değerlere ve anlamlara sahip bir şey olarak düşünmektedir. Bireyin sahip olduğu ya da elde etmek amacıyla mücadele verdiği sermayeler, alanda eyleyici konumdaki bireylerin kurduğu toplumsal ilişkiler doğrultusunda anlam ve değer kazanmasından dolayı nihayetinde toplumsal boyuttadır (Calhoun, 2016: 107). En genel eksende ekonomik, kültürel, sosyal olmak üzere üç sermaye türü toplumsal alanlarda yer almaktadır (bu üç sermayenin nesneleșmiş formu olarak sembolik sermaye de dördüncü sermaye türü olarak belirtilir). Elbette bu üç sermaye türüne dönüştürülebilecek bedensel/fiziksel sermaye, entelektüel/akademik sermaye gibi alt türler bulunmakla birlikte çoğu alanda karşlaş̧lan sermaye türleri bu dört tür olarak karşımıza çıkmaktadır.

Toplumsal alanda her biri kendi özgü alt sermaye biçimlerine (sportif sermaye, bilimsel sermaye, entelektüel sermaye vb.) sahip olan üç temel sermaye türü mevcuttur. Bireyin ihtiyaç dahilinde parasal kazanca dönüștürebileceği mal, mülk ve çeşitli metalardan oluşan ekonomik sermaye, alan içerisinde egemen konumda bulunanların doğru ya da olması gereken olarak kabul ettiği ve empoze etme gayreti içinde olduğu, bireye sosyalizasyon sürecinde aile ve okul gibi kurumlarca aktarlan edinimler olarak (Arun, 2009: 79) tanımlanabilecek kültürel sermaye- Bourdieu'nun en çok üzerinde durduğu sermaye türüdür ve kendi içinde eğitim ve bilgi birikimine bağlı olarak kişinin tavır, davranış ve tutumlarıyla ortaya çıkan somutlaştrılmış kültürel sermaye, bireyin akademik niteliğine ve sıfatlarına dayandığını söyleyebileceğimiz kurumsallaştırılmış kültürel sermaye ve son olarak kültürel değerlere referansta bulunan çeșitli objelerle ortaya çıkan nesneleştirilmiş kültürel sermaye olarak üç alt biçime ayrılır- ve bireyin alan içerisinde çevresi ile kurduğu ilişkiler ağının niteliğine dayalı olan ve diğer sermayelerin büyüklüğüne bağlı olarak değişen sosyal sermaye adıyla üç belirleyici sermaye türü bulunmaktadır. Ayrıca, bu üç temel sermaye türünün belirli bir toplumsal algıyla nesneleşmiş ya da metalaşmış biçimi olan simgesel (sembolik) sermaye türü de bu üç sermaye türüyle beraber dördüncü temel sermaye biçimi olarak Bourdieu tarafından ifade edilmektedir (Bourdieu ve Wacquant, 1992: 119).

Toplumsal uzamın parçası olan bir toplumsal alan olarak spor alanının da doğası gereği belirli sermaye biçimlerini bünyesinde barındırması kaçınılmaz bir durumdur. Toplumsal uzamın medya, ekonomi, siyaset, eğitim gibi pek çok noktasına sirayet etmiş durumda olan spor alanında hemen her sermayenin alan içerisindeki varlığından rahatlıkla söz edilebilmekle birlikte, Bourdieu'nun sermaye kavramının spor alanındaki varlığı ve etkinliği üzerine önemli çalışmalar da karşımıza çıkmaktadır. 
Ekonomik sermaye türünün, kendi devasa ve karmaşık ekonomik yapılanması gözler önünde olan spor alanı için kaçınılmaz bir sermaye türü olmasının yanında kültürel ve sosyal sermaye türleri de spor alanının pek çok noktasında alan içerisinde faaliyetlerini sürdürme gayreti içerisinde olan bireyler ve gruplar için son derece etken konumdadır.

Sermaye türleri içerisinde en çok üzerinde durulan kültürel sermayeden başlamak gerekirse, esasında ilk bakışta kültürel sermayenin, Bourdieu'nun da belirttiği üzere, eğitim hayatı ve gençlik yılları olarak nitelendirdiğimiz dönemlerde spor alanında yer alma konusunda bir etkisi söz konusudur. Bireyin edinmiş olduğu kültürel sermaye ve buna paralel olarak içerisinde bulunduğu toplumsal sınıfın pratikleri o bireye yönelmesi ya da yönelmemesi gereken sportif branşlar hakkında rehberlik etmektedir. Diğer yandan, kültürel sermaye kavramı çerçevesinde açılayıcı bir örnek Jožef Križaj, Bojan Leskošek, Janez Vodičar ve Mojca Doupona Topič'in Bourdieu'nun temel kavramları ekseninde hareket ederek birlikte yürüttükleri, 2016 yllında yayınlanan ve küresel boyutta sporcu göçü üzerinden Bourdieu'nun kültürel sermaye biçiminin sporcuların tercihlerindeki etkilerini ortaya koymayı hedefleyen "Soccer Players, Cultural Capital and Its Impact on Migration (Futbolcular, Kültürel Sermaye ve Göç Üzerindeki Etkileri)" adlı çalışmasıdır. Çalışmada elde edilen veriler ışı̆̆ında yapılan açıklamaya göre, ekonomik sermayenin spor alanındaki etkinliğine ek olarak, profesyonel bir futbolcunun spor alanında kendini tanımlaması ve geliştirmesi hususunda somutlaştırılmış ve kuramsallaştırılmış kültürel sermaye türlerinin ayrıca önemli bir etkisi olduğu ortaya koyulmaktadır. Özellikte Avrupa'nın beş büyük futbol ligini (İngiltere, Almanya, İspanya, İtalya ve Fransa futbol ligleri) örnek gösteren araştırmacılar, küresel çaptaki sporcu göçü ve kültürel sermaye arasındaki ilişkiye dikkat çekmektedir. Gündelik hayatını çevreleyen toplumsal yapılardan ve sosyalizasyon süreçlerinden etkilenen profesyonel bir sporcunun küresel çapta isim yapmış bir futbol liginde ve yüksek profilli bir spor kulübünde yer almayı tercih etmesi spor alanı içerisinde somutlaştırılmış ve kurumsallaştırılmış kültürel sermaye biçimlerine birer örnek teşkil etmektedir. $\mathrm{Bu}$ nedenle, profesyonel sporcunun zaman içerisinde deneyimler ve aktarımlar sonucu ürettiği stratejinin -ki bu strateji hangi ülke ve takımda spor hayatını sürdürmesinin doğru ya da avantajlı olacağı üzerinedir- kültürel sermaye temelli olmasıdır. (Križaj, vd, 2016: 196).

Toplumsal alanlardaki ilişki ağları ile gelişen sosyal sermaye türü ve spor alanındaki varlı̆̆ı üzerine bir örnek içinse Peter Alegi'nin Afrika kıtasında yine futbol alanındaki eyleyiciler üzerine yürüttüğü 2000 tarihli "Keep Your Eye on the Ball: A Social History of Soccer in South Africa" isimli çalıșması gösterilebilir. Bourdieu'nun sosyal sermaye kavramını alan içerisinde kurulan ilişkilere dayandıran Alegi Afrika kıtasındaki futbol alanı üzerine yürüttüğü çalışmasında iktidarda olan ya da toplumsal yaşamda bir şeyleri değiștirebilme kapasitesine sahip konumda bulunan bireylerin ve siyasi alanda etkinliği olmayan bireylerin futbol alanında sosyal sermayeleri ile yarattığı etkiyi incelemiștir. Alegi'nin sosyal sermaye ve futbol alanı arasındaki ilişkiye dair ortaya koyduğu açıklama ise, bölgesel ya da yerel düzeyde futbol alanının (ya da daha genelde spor alanı olarak düşünülebilir) yeni ilişkiler, bağlantılar ve görünürlüğü mümkün kılma avantajlarından dolayı bir sosyal sermaye biçimi yarattığı, bu sayede spor alanının bireyin kendi hareket alanını genişleterek kendi kendini geliştirmeye ciddi katkı sağladığı yönündedir (Alegi, 2000). Bireyin sahip olduğu sosyal sermaye spor alanının herhangi bir noktasına yönelmesinde etkin olabileceği gibi, Alegi'nin çalışmasından yola çıkarak, bireyin spor alanı içerisinde ürettiği stratejiler ekseninde faaliyetlerini sürdürürken alana özgü bir sosyal sermaye edinebilme imkanının varlı̆̆ından da söz edilebilmektedir.

Ekonomik, kültürel ve sosyal sermayelerin spor alanındaki varlığı ve önemi dışında, bu alana özgü dönüștürülebilir bir sermaye türünden de söz etmemiz gerekiyor. Sermaye türlerinin Bourdieu perspektifinde sabit, değişmez bir yapısının olmadığı ve diğer sermaye türleri ve 3 temel sermaye türünün alt türleri ile dinamik bir ilişki söz konusudur. Bu nedenle, sermaye türlerinin değişkenliği ve dönüștürülebilme kapasitesini göz önünde bulunduracak olursak, spor alanına katılımda ve alan içerisinde bir pozisyon üstlenebilme açısından, özellikle sporcular için bir alt sermaye türü olarak fiziksel/bedensel sermayenin ayrıca ciddi öneminden bahsedilebilir (diğer sermayelerin spor alanındaki sporcular için öneminin olmadığı anlamı çıkarılmamalıdır). 
Fiziksel/bedensel sermaye, alan içerisinde bireyin fiziksel görünüşü ve fiziki kapasitesi üzerinden toplumsal, kültürel ya da ekonomik kaynaklara ulaşabilme yetisine imkân vermektedir (Shilling, 2004: 474). Bourdieu'ya göre sportif alanlar, güzellik ya da kabul edilmiş fiziksel mükemmellik gerektiren alanlar (güzellik yarışmaları, moda organizasyonları gibi) eyleyicinin kendi bedeniyle kurduğu ilişkinin bir boyutudur ve fiziksel/bedensel sermayeye yatırım toplumsal alanlardaki diğer kaynakları (ekonomik sermaye, sosyal sermaye gibi) edinebilmenin kabul edilir bir yöntemidir (Bourdieu, 2015c: 109-111). Bedensel/Fiziksel sermaye türüne uygun bir örneği Loic Wacquant boksörler üzerine yaptığı çalışmasında (bkz. Body \& Soul: Notebooks of an Apprentice Boxer, 2006) ifade etmektedir. Wacquant güç ve cesaret gerektiren bir alan olarak tanımladığı boks alanında faaliyet gösteren boksörlerin bedenlerini emek harcanması, geliştirilmesi ve muhafaza edilmesi gereken bir sermaye biçimi olarak nitelenmektedir (Wacquant L. , 2012: 138-139). Ayrıca Wacquant, Bourdieu'nun sermaye tanımlamasına paralel olarak, boksörler (ve boksörlere diğer dallarda mücadele eden profesyonel sporcular da rahatlıkla dahil edilebilir) bedensel sermaye sahipleridir ve bir sermaye biçimi olarak bedenlerini şöhret, unvan, sembolik ödüller ve ekonomik kazanca dönüștürebilmek adına geliștirmesi ve koruması gereken işletmesidir. Bir sporcunun bedeni hem sporcunun üretim aracı hem hammaddesi hem de geçmişteki çalışmalarının ve biriktirdiği emeğinin bedenleşmiş halidir (Wacquant L. , 2015: 122-123). Ancak, fiziksel sermaye diğer sermaye türlerine dönüștürülebilir nitelikte olmasına ve eyleyicinin alan içerisinde yatay ve dikey ilerleyişlerini mümkün kılmasına rağmen bazı dezavantajlar barındırmaktadır. Shilling'e göre, bireyin bedeninin gücü, hızı ve çevikliğinin spor alanı içerisinde bir sermaye biçimi olarak diğer farklı sermayelere (özellikle ekonomik sermayeye) dönüșebilme potansiyeli taşımakla birlikte, bedensel sermayelerine ciddi yatırımlar yapanların çok küçük bir kısmının sportif alanda başarılı olabilmesi, kültürel ve sosyal sermayeden yoksun bireylerin bu alanda kendilerini geliştirme konusunda dezavantajlı konumda bulunması, insan vücudunun kırılganlığı ve spor kariyerinin ortalama süresinin düşüklüğü gibi ciddi riskler barındırmaktadır (Shilling, 2004: 477).

\subsection{Habitus ve Spor Alanında Eylem Şemaları}

Bourdieu sosyolojisinde önem arz eden ve hala güncelliğini koruduğunu iddia edebileceğimiz kavramlardan habitus kavramıssa, ayrı bir öneme sahip olmakla birlikte belki de Bourdieu'nun hemen her çalışmasında belirttiği ve onun ismiyle en çok anılan ve özdeșleșen yegâne kavram konumundadır. Bourdieu çalışmalarında habitus kavramını ifade edebilmek adına "alışkanlık oluşturan güç", "temel derinlemesine içselleştirilmiş büyük örüntüler", "zihinsel alışkanlık", "zihinsel ve bedensel algı, beğeni ve eylem şemaları", "düzenli doğaçlamaların üretici ilkesi" gibi pek çok ifade biçimine yer vermektedir (Swartz, 2011: 145). Kısa bir ifadeyle belirtmek gerekirse habitus, bireylerin toplumsal yaşamı anlamlandırmalarını ve belirli bir değer atfetmelerini mümkün kılan "zihinsel ya da bilişsel yapılar" olarak açılanabilir (Ritzer, 2012: 398). Bu açıklamadan yola çıkarak, bireyin edindiği habitusunu sosyalizasyon süreci içerisinde kurmuş ve kurmakta olduğu ilişki ve etkileşimler üzerinden edindiği yatkınlıklar olarak ifade edebiliriz.

Bourdieu Ayrım-Beğeni Yargısının Toplumsal Eleștirisi isimli önemli çalışmasındaki örneklerinden birinde, bireylerin spor aktivitelerinden beklentilerinin, bir sporu tercih etmenin ya da tercih etmemenin bireylerin ait oldukları sınıfa göre çeşitli farklılıklar gösterdiğinin üzerinde durmaktadır. Bourdieu'ya göre, bireyin içselleştirdiği yatkınlıklar (habitus), bedeni ile kurduğu ilişki ve bir parçası olduğu toplumsal sınıf, spor alanındaki tercihlerinde önemli bir etkiye sahiptir. Farklı toplumsal sınıfların farklı spor dalları üzerine yoğunlaşmasıyla ortaya çıkan bu durum kendiliğinden bir kitle sporu ve elit sporu ayrışmasına yol açmaktadır. Bourdieu, en önemli çalışmalarından biri olarak başvurabileceğimiz Ayrım'da bu analizini şu şekilde açıklar:

"Sınıflar arasında farklı spor türlerinin dağılımını anlamak, sınıflar için, sporların kendilerine özgü algı ve değerlendirme kalıpları uyarınca temsil ettikleri farklı maliyet (ekonomik, kültürel ve "fiziksel") ve faydaları dikkate almakla mümkündür: kısa veya uzun vadeli fiziksel faydalar (sağlık, güzellik ve güç -vücut geliştirmede görünür ya da form korumada görünmez olan- vs.); iktisadi ve toplumsal faydalar (toplumsal terfi vs.); söz konusu sporların her birinin dağılımsal ve konumsal değerlerine (yani ender ya da yaygın olmaları ve az ya da çok açık biçimde bir 
sınıfa atfedilmelerinden dolayı ortaya çıkanlar -boks, futbol, rugby veya vücut geliștirmenin halk sınıflarına, tenis ve kayağın burjuvaziye ve de golfün büyük burjuvaziye atfedilmesi gibi) bağlı olan kısa ve uzun vadeli sembolik faydalar; bizatihi beden üzerinde harcanan çabayla yaratılan (örneğin zayıflık, bronzlaşma, az ya da çok belirgin olan kaslanma) ya da bazı sporların (golf, polo vs.) ortaya çıkardığı yüksek derecede seçici gruplara erişim ile yaratılan ayrışma faydası gibi. (Bourdieu, 2015a: 122)."

Ancak, spor alanında belirli dallar arasında belirli dönemlerde bu ayrışma dönüşebilmekte ya da iç içe geçebilmektedir. Buna paralel olarak, aynı spor alanında bulunan farklı sınıftan bireylerinde zıtlık içerdiğini belirten Bourdieu, ait oldukları sınıfın ve elbette habituslarının farklılığıyla doğru orantılı olarak aynı spora katılan bireylerin spora katılıș nedenlerinin, spor faaliyetinden beklentilerinin ve spor yapma tarzlarının tamamen farklı olacağını ileri sürerek bu durumu açıklamaktadır (Bourdieu, 2015a: 306-317). Sportif aktivitenin uygulanışı noktasındaki bu farklılığın nedeni ise Bourdieu'ya göre, bireylerin ait olduğu toplumsal grubun ya da sınıfın ve buna paralel olarak bireyin habitusunun devamlı olarak ayrıștırıcı pratikler doğurmasından kaynaklanmaktadır (Bourdieu, 2015b: 22). Bourdieu spor alanındaki tarihselliği ve sınıflar arasındaki beğeni çatışmasının spor alanındaki tezahürünü yine aynı çalışmasında detaylı olarak belirtir:

\begin{abstract}
"Şurası bir gerçek ki, eğer sadece sınıflar arasında hemen hemen eşit paylaşılmış yetenekleri ("fiziksel" veya sonradan edinilmiş) gerektiren, boș zaman ve fiziksel enerji sınırlılıklarına bağlı olarak erişilebilir olan takım sporlarının erişilirlikleri ve bununla bağıntılı istenmeyen toplumsal temaslar gibi nitelikleri egemen sınıf mensuplarını caydırmasayd, bireysel sporlar gibi, takım sporlarının da toplumsal hiyerarșide yükselindiği ölçüde daha da sıklıkla görülmesi beklenebilirdi. İște bu yüzden, popüler sporların en tipiği olan futbol ile rugby veya güreş ile boks, Fransa'da ortaya çıktıkları zaman soylulara özgü iken (en azından, sayıları hiçbir zaman çok yüksek olmayan ve züppeliklerini bu etkinliklerle taçlandıran bir kısım soylulara özgü), yaygınlaşarak ve avamlaşarak, eskiden egemen sınıftakilerin gözünde büründükleri değerleri (gerçekte ve algıda) taşımayı bırakıp, bu sınıfın mensuplarını uzaklaştırmak için geçerli tüm nedenleri biriktirirler: Avamlaşma, bu sporların yayılmaları sonucunda onları yeni benimseyen kitlenin toplumsal bileșimi nedeniyle ikiye katlanır; aynı zamanda, yeni atfedilen değer ve erdemlerden güç, kötüye direnme, "fedakarlık" ruhu, itaatkarlık, disipline toplu boyun eğiş ile burjuvaların beklediği müsabakanın yüceltilmesinde beliren "role olan mesafenin" mükemmel antitezini oluşturur (Bourdieu, 2015a: 314-315)."
\end{abstract}

Sportif aktivitenin uygulanışı noktasındaki bu farklılığın nedeni ise Bourdieu’ya göre, bireylerin ait olduğu toplumsal grubun ya da sinıfın ve buna paralel olarak bireyin habitusunun devamlı olarak ayrıştırıcı pratikler doğurmasından kaynaklanmaktadır (Bourdieu, 2015b: 22).

Bireyin toplumsal ilişkiler ve sınıfsal yapılar ekseninde edindiği habitusunun spora yönelmesi (daha özelde hangi spor dalına yönelmesi gerektiği) hususunda belirleyici olduğu gerçeğinin dişında, bir spor alanı içerisinde faaliyetlerini sürdüren ve belirli stratejiler üreterek arzuladığı sermayelere ulaşma gayreti içerisinde olan eyleyici bulunduğu alandan da etkilenerek habitusun şekillenmesinin önünü açmaktadır. Başka bir ifadeyle, spor alanında faaliyet gösteren birey zamanla bir sporcu habitusu edinmektedir. Spor alanında Bourdieu sosyolojisinin sayıltıları üzerinden üretilen bir çalışmadan örnek vermek gerekirse, Wacquant'ın boksörler üzerine yaptığı çalışmasında spor alanında edinilen "dövüşçü habitusu" üzerine açıklamaları önemlidir. Wacquant’a göre, dövüştü habitusu olarak adlandırdığı şey alan içerisinde faaliyetlerini sürdürebilmek ve kendini var edebilmek adına yetkin bir boksörün zamanla edinmesi kaçınılmaz olan fiziksel ve zihinsel özgün şemalardan ibarettir ve boks alanına özgü olarak bu alan içerisinde edinilebilir (Wacquant, 2015: 31). Benzer bir habitus örneğini Simon Beames ve John Telford 2013 yılında yayınladıkları "Pierre Bourdieu: habitus, field and capital in rock climbing" çalışmasında ifade etmektedir. Çalışmaya göre, farklı toplumsal sınıflara ve sermaye birikimlerine sahip olmakla birlikte kaya tırmanışı alanında faaliyet gösteren sporcular bu alana özgü yatkınlıklara sahip olmaktadırlar (Beames \& Telford, 2013: 81). Bourdieu'nun spor ve habitus ilişkisi üzerine yaptığı açılamalar ve verilen örnekler üzerinden, habitus kavramının spor alanına katılımda, sporun herhangi bir türünün tercih edilmesinde ve katılım-tercih ekseninde bireyin belirlediği hedef ve çıkarlarda bireyler için bir kılavuz niteliği 
taşımasının yanı sıra, bir spor alanı içerisinde faaliyet gösteren sporcuların o spor alanında faaliyet göstermeyi mümkün kılan çeşitli yatkınlıkları da içselleştirecekleri ifade edilebilir.

Genel anlamda Bourdieu sosyolojisinin sayıltıları ve spor alanı arasındaki bağlantı noktalarını ifade etmek gerekirse, Pierre Bourdieu'nun ortaya koyduğu temel kavramlar olarak nitelendirebileceğimiz alan, sermaye türleri ve habitus toplumsal uzamın bütün alt alanlarında gözlemlenebildiği gibi spor alanında da araştırmacıların karşısına çıkmaktadır. Birbirleriyle ilişkili ve tamamlayıcı bir özelliğe sahip bu kavramlar, çeșitli çalıșmalardan örneklerle sunulduğu gibi, spor alanını var eden ilişki ağlarını ve elbette spor alanı içerisinde bu ilişki ağlarının oluşmasını mümkün kılan sporcuların deneyim ve pratiklerini anlama ve açıklama hususunda oldukça önemli avantajlar sunmaktadır. Bu noktada belirtilmesi gereken son bir nokta da Bourdieu'nun bu konudaki açıklamaları üzerinden, buraya kadar bahsettiğimiz teorik çerçeve ekseninde bir spor alanının Bourdieu sosyolojisi üzerinden hangi adımların ve yöntemlerin izlenerek araștırılması gerektiği olacaktır. Bu konuda Bourdieu, spor ve sosyolojisi ilişkisi ve spor alanında yürütülecek sosyolojik bir çalışmanın kendi perspektifi üzerinden nasıl olması gerektiği (ya da olabileceği) yönünde aydınlatıcı açıklamalar sunmaktadır.

\section{$4 \quad$ Spor Sosyolojisinin Neliği}

Spor ve sporun sosyolojisi üzerine yaptığı açıklamalarda ve eserlerinde belirttiği spor alanı örneklerinde çoğunlukla tarz, beğeni, beden ve pratik gibi kavramları kullanarak spor ve sınıf arasındaki ilişkiye değinen ve özellikle elit sporu, halk sporu ya da kitle sporu gibi ayrımlara ve sporun alt alanlarındaki belirli değişkenliklere dikkat çeken Bourdieu, spor alanında sosyolojik bir araștırma yürütmede karșllaşılan engeller ve spor alanında yürütülen sosyolojik bir araștırmanın nasıl olması gerektiği ya da nasıl olabileceği konusu üzerinde de durmaktadır. Özellikle teorik çerçevesi üzerinden eserlerinde verdiği örneklerle spor alanına değinen Bourdieu ayrıca, belirtildiği gibi spor sosyolojisi ve spor alanının araştırma pratiği üzerine de bazı açıklamalarda bulunmuştur.

İlk olarak Bourdieu'nun spor ve sosyoloji arasındaki mesafeli iliş̧i üzerine yaptığı açıklamalar önem arz etmektedir. Bourdieu'ya göre, spor uzamı ve spor türlerinin sosyolojik çerçevede araştırılmasının önünde kalıplaşmış bazı önyargılardan kaynaklı engeller yer almaktadır. Toplumsal iş bölümü mantığının akademik alanda da varlığını sürdürdüğünü belirten Bourdieu, spor konusunun akademik alanda görmezden gelindiğini, spor alanında ise önemsenmediği iddiasındadır (benzer bir açıklamayı spor sosyolojinin ilk çalışmalarından kabul edilen "Toward a Sociology of Sport" çalışmasında Kenyon ve Loy da ifade etmektedir). Bu nedenle, bir tarafta spor alanının işleyişi ve uygulanması hususunda gerekli donanıma sahip, ancak akademik olarak bu konuyu araştırabilecek düzeyde olmayan bir grup, diğer yandan akademik alan içerisinde bu konu hakkında konuşabilecek, ancak spor alanına tamamen ilgisiz ayrı bir kitle yer almaktadır (Bourdieu, 2016a: 53-54). Bu düşünceden yola çıkarak, Bourdieu'ya göre spor uzamında yapılan bir araştırma sürecinde uzamın uygulanış şekli ve genel işleyişi hakkında yeterli bilgi sahibi olmak, derinlemesine bir sosyolojik araştırma için ön koşul durumdadır. Bu ön koşulun gerekliliğine dair belki de en önemli örneklerden birisi, çalışmanın önceki başlıklarında da bahsettiğimiz verdiğimiz, Loic Wacquant'ın Bourdieu'cu bir perspektiften boksörler üzerine yürüttüğü ve daha sonra 2006 yılında Body ve Soul, Notebooks of Apprentice Boxer (Ruh ve Beden, Acemi Bir Boksörün Defterleri) ismiyle yayınlanan çalışmasıdır. Yayınlanan çalışmanın hemen başında Wacquant, boksörler üzerine yaptığı araştırma sürecinin başında, daha net ve derinlemesine bir analiz yapabilmek ve alanın işeyişini kavrayabilmek amacıyla 1988-1991 yılları arasında aktif olarak düzenli bir şekilde boks antrenmanlarına katıldığını belirtmektedir (Wacquant L. , 2015: 17-18). Boks alanında aktif olarak geçirdiği yaklaşık üç yıllık zaman dilimi Wacquant'a alan içerisinde boksörlerin haricinde, boks alanında belirli bir konuma sahip isimlere ve boks alanının her köșesine erişimi sağlamıș ve alanın derinlemesine bir analizini de mümkün kılmıştır.

Bourdieu'nun açıklamasına göre, spor üzerine yürütülen bir çalışmada ilk öncelik o spor alanının tarihsel arka planını ve deneyimlenen süreçleri iyi kavrayabilmektir, çünkü sadece bu şekilde spor 
özgün bir alan olarak indirgemeci anlayıştan uzak ve üzerine konuşmanın mümkün olduğu bir hal alabilir. Bunun yanı sıra, toplumsal yaşamın bir parçasını oluşturan spor alanının görece özerk bir şekilde kendine has belirli ödülleri, kuralları, bünyesinde barındırdığı eyleyicileri ve elbette bütün bunların arasındaki ilișkiler ağını kavrayabilmek spor alanında sosyolojik bir araştırmayı gerçekleștirmenin gereklilikleri konumundadır (Bourdieu, 2015c: 97-98). Burada spor sosyolojisinin 50-60 ylllk tarihsel süreci içerisinde belirtmemiz gereken nokta, spor alanında yapılan çalışmalarda Bourdieu sosyolojisin kullanımının ön plana çıkarılmasıyla birlikte (Bourdieu'nun yanında Norbert Elias ve Eric Dunning isimleri de rahatlkkla eklenebilir) spor sosyolojisi alanında salt nicel ve istatistiksel verilerin ön plana çıkarıldığı makro boyuttaki sosyal bilim anlayışına güncel ve önemli bir alternatif de yaratılmıştır. Bourdieu sosyolojisinin tarihselliğin önemine vurgu yapan ve çeşitli kalıplaşmış ikililikleri aşma çabası içerisinde olan refleksif ve ilişkisel sosyal bilim anlayışı spor alanında da son derece kullanışlı bir yaklaşım ve teorik çerçeve konumuna yerleşmektedir.

\section{Sonuç ve Öneriler}

İnsanlık tarihiyle neredeyse aynı paralellikte ilerleyen ve sanayi devrimiyle birlikte toplumsal yaşamın hemen her noktasında kendinden söz ettiren sportif faaliyetler, artık günümüzde küresel boyutlara ulaşmış, kendi ekonomisi ve kültürel pratikleriyle devasa bir özerk toplumsal alan konumuna gelmiştir. Spor alanının bu denli büyük gelişimi de elbette sosyal bilim alanında son derece özel bir çalışma alanı olarak kabul edilmesini sağlamıştır.

Genel anlamda yaklaşık iki yüzyıldır, organize bir alt disiplin olarak da 50 yıla yakın bir süredir sosyoloji alanını meşgul eden spor alanı, sosyolojinin bir alt alanı olarak pek çok araştırmacı tarafından klasik ve modern dönem sosyolojik yaklaşımlar ve kavramlar üzerinden değerlendirilmeye alınmıştır. Ağırlıklı olarak işlevselci teorinin ekseninde istatistiksel olarak makro boyutlarda ele alındığı başlangıç döneminden başlayarak Marxist/çatışmacı, sembolik etkileşimci ve feminist perspektifler gibi sosyolojinin hemen her yaklaşım ekseninde değerlendirilen spor alanı, paradigma tartışmalarının yaşandığı 1980'li yıllardan itibaren, önemli ölçüde çok daha bütünlükçü, ikilikleri aşma hedefi taşıyan teorilerin sayıltıları üzerinden ele alınmaya başlamıştır. Bu dönemle birlikte de Norbert Elias ve Eric Dunning gibi figürasyonel sosyolojinin yanı sıra Pierre Bourdieu'nun eylem teorisi ve sosyolojik yaklaşımı da spor sosyolojisi alanında üretilen çalışmalarda kendisine yer bulmaya başlamıştır.

Genel olarak Bourdieu'nun kendi teorik çerçevesi ve sosyoloji anlayışı ekseninde açıklamalarda bulunduğu spor alanının incelenmesinde üzerinde durduğu noktalar, "oyun metaforu" ile yaptığı açıklamalardan ve oyun metaforunu incelerken karşılaşılan kavramsal çerçeveden çok da farklı değildir. Çalışmalarında teorik çerçevesine dair açıklayıcı bir örnek olarak sunduğu ya da salt spor alanı ekseninde yaptığı açıklamalarında Bourdieu, spor üzerine sosyolojik bir çerçevede analizin ve açıklamalar yapabilmenin mümkün olabilmesi için sporun belirli ölçüde özerk, kendi iç dinamiklerine sahip bir alan olması, bu alanın içinde barındırdığı ve karşılıklı ilişkiler ağının var olabilmesini sağlayan eyleyicilere ihtiyacı olduğunu vurgulamaktadır. Bu anlayışa paralel olarak, Bourdieu perspektifinden spor alanı hakkında konuşabilmenin mümkün olması için, toplumsal uzamın bu alt alanının nasıl inşa edildiğini, alanın tarihsel boyutunu ve toplumsal yaşamda alanın meydana gelmesini mümkün kılan ilişki ağlarını ortaya koymak ilk etapta önem arz etmektedir. Akabinde alana katılımı ve mücadele/rekabet etmeyi cazip kılan sermaye türleriyle, oyuncuların hem spor alanına katılımlarını mümkün kılan hem de spor alanı içerisinde stratejiler üreterek alanda var olabilme adına edindikleri yatkınlıkları (habitusları) kavrayabilmek önem taşımaktadır. Ayrıca, spor alanının işleyişini ve süreç boyunca sporcuların bu alandaki konumlanışı da günümüzde spor alanının ve sporcuların konumunu anlamak ve açılklamak açısından da önem arz etmektedir. Bütün bu açıklama ve değerlendirmelerden yola çıkarak, Bourdie'nun ortaya koyduğu teorik çerçeve ve ilişkisel kavramlar, toplumsal yaşamın alt alanı olarak spor alanında yaratılan kültür ve pratikleri, sportif alanları karakterize eden ve sosyalizasyon, toplumsal sinıf ve cinsiyetten etkilenen alışkanlıkların (habitus) inşasında, farklı sermaye türlerinin çeşitli türevlerinden yararlanan 
sporcuların beklentileri ve stratejilerinin analiz edilmesi ve anlaşılması hususunda spor sosyolojisine önemli ve alternatif bir bakış açısı kazandırdığı ifade edilebilir.

\section{Kaynakça}

Alegi, P. C. (2000) Keep Your Eye on the Ball: A Social History of Soccer in South Africa, 1910-1976. Doctoral dissertation, Boston University, Boston.

Arun, Ö. (2009). Yaşlı Bireyin Türkiye Serüveni: Türkiye'de Yaşlı Bireyler Arasında Kültürel Sermaye Dağılımı. Gaziantep Üniversitesi Sosyal Bilimler Dergisi, 8(1), s. 77-100.

Baert, P. (1998). Social Theory in Twentieth Century. New York: New York University Press.

Beames, S., ve Telford, J. (2013). Pierre Bourdieu: Habitus, Field and Capital in Rock Climbing. In Outdoor Adventure and Social Theory (s. 77-87). London: Routledge.

Bourdieu, P. (1997). Toplum Bilim Sorunları. İstanbul: Kesit Yayıncllı.

Bourdieu, P. (2015a). Ayrım Beğeni Yargısının Toplumsal Eleştirisi. Ankara: Heretik Yayıncılık

Bourdieu, P. (2015b). Pratik Nedenler -Eylem Kuramı Üzerine. İstanbul: Hil Yayın.

Bourdieu, P. (2015c). Spor ve Toplumsal Sinıf. İ. Hacısoftaoğlu, F. Akcan, ve N. Bulgu içinde, Oyunun Ötesinde Spor Sosyolojisi Çalışmaları (s. 95-118). Ankara: Notabene Yayınları.

Bourdieu, P. (2016a). Seçilmiş Metinler. Ankara: Heretik Yayıncılık.

Bourdieu, P. (2016b). Sosyoloji Meseleleri. Ankara: Heretik Yayıncıllk.

Bourdieu, P., ve Wacquant, L. (1992). An Invitation to Reflexive Sociology. Cambridge: Polity Press.

Calhoun, C. (2016). Bourdieu Sosyolojisinin Ana Hatları. G. Çeğin, E. Göker, A. Arlı, ve Ü. Tatlıcan içinde, Ocak ve Zanaat- Pierre Bourdieu Derlemesi (s. 77-130). İstanbul: İletişim Yayınları.

Collins, T. (2013). Sport in Capitalist Society: A Short History. New York: Routledge.

Cuff, E. C., Sharrock, D. W., ve Francis, D. W. (2015). Sosyolojide Perspektifler. İstanbul: Say Yayınları.

David M. ve Aaron M. (2006) 'Football is My Life': Theorizing Social Practice in the Scottish Professional Football Field, Sport in Society, 9:3, s. 371-387, DOI: 10.1080/17430430600673381

Dever, A. (2010). Spor Sosyolojisi: Tarihsel ve Güncel Boyutlarıyla Spor ve Toplum. İstanbul: Başlık Yayın Grubu.

Delaney, T. ve Madigan, T. (2015). The Sociology of Sports: An Introduction. Jefferson, North Carolina: McFarland.

Edwards. H. (1973) Sociology of Sport. Homewood-IL: Dorsey Press.

Fişek, K. (1985). 100 Soruda Türkiye Spor Tarihi. İstanbul: Gerçek Yayınevi.

Hilgers, M. ve Mangez, E. (2015). Introduction to Pierre Bourdieu's Social Fields. M. Hilgers, ve E. Mangez içinde, Bourdieu's Theory of Social Fields: Concepts and Applications (s. 1-36). Routledge Press.

Jourdain, A. ve Naulin: (2016). Pierre Bourdieu'nün Kuramı ve Sosyolojik Kullanımları. İstanbul: İletişim Yayınları.

Kenyon, G. S. ve Loy, John W. (1965) Toward a Sociology of Sport, Journal of Health, Physical Education and Recreation Journal, 36 (5): s. 24-69.

Križaj J., bLeskošek B., Vodičar J., Topič M., (2016) Soccer Players Cultural Capital and Its Impact on Migration, Journal of Human Kinetics, (54), s. 195-206 
Loy J. W. ve Booth D. (2000). Functionalism, Sport and Society. Coakley J. ve Dunning E. içinde Handbook of Sports Studies (s. 8-27). London: Sage Publitions

Ritzer, G. (2012). Modern Sosyoloji Kuramları. Ankara: De Ki Basım Yayım.

Shilling, C. (2004). Physical Capital and Situated Action: A New Direction For Corporeal Sociology. British Journal of Sociology of Education, 25(4), s. 473-487.

Souza, J. (2010). "For Origin of the Field of the Sociology of the Sport: Sceneries and You Put In Perspective." Movimento : Revista da Escola de Educação Física 16, s. 45-70.

Swartz, D. (2011). Kültür ve İktidar Pierre Bourdieu'nun Sosyolojisi. İstanbul: İletişim Yayınları.

Swartz, D. (2015). Bourdieucü Perspektiften Sosyolojik Analiz İçin Meta-ilkeler. P. S. Gorski içinde, Bourdieu ve Tarihsel Analiz (s. 41-65). Ankara: Heretik Yayıncllık.

Talimciler, A. (2015). Sporun Sosyolojisi Sosyolojinin Sporu., 2. Basım Ankara: Bağlam Yayıncllık.

Tatlıcan, Ü. ve Çeğin, G. (2016). Bourdieu ve Giddens: Habitus veya Yapının İkililiği. G. Çeğin, E. Göker, A. Arlı, ve Ü. Tatlıcan içinde, Ocak ve Zanaat Pierre Bourdieu Derlemesi (s. 303-366). İstanbul: İletişim Yayınları.

Timur, T. (2011). Marksizm, İnsan ve Toplum Balibar, Sève, Althusser, Bourdieu. İstanbul: Yordam Kitap.

Tittenbrun, J. (2016). Concepts of capital in Pierre Bourdieu's theory. Miscellanea Anthropologica et Sociologica

Wacquant, L. J. (2012). Ruh ve Beden. Acemi Bir Boksörün Defterleri. İstanbul: Boğaziçi Üniversitesi Yayınevi.

Wacquant, L. J. (2015). İşleyen Boksörler: Profesyonel Boksörler Arasında Bedensel Sermaye ve Bedensel Emek. İ. Hacısoftaoğlu, F. Akcan, ve N. Bulgu içinde, Oyunun Ötesinde Spor Sosyolojisi Çalışmaları (s. 119-157). Ankara: Notabene Yayınları.

Wallace, R. A. ve Wolf, A. (2013). Çağdaş Sosyoloji Teorileri- Klasik Geleneğin Genişletilmesi. Ankara: Doğu Batı Yayınları.

Yiannakis, A., Merrill M. ve Troy M. (2019). Sociology and the Origins of NASSS: The Early Years 19551980. Iowa, s. 9-19.

Young, D. C. (2004). A Brief History of the Olympic Games. Malden: Blackwell Publishing.

\section{Kaynak Gösterimi / Cite This Article}

APA:

Bozlu, B. (2020). Pierre Bourdieu Sosyolojisi ve Spor Alanının İnşası. Sosyolojik Bağlam Dergisi, 1(1), 13-26.

Bozlu, B. (2020). Sociology of Pierre Bourdieu and Construction of Sports Field. Journal of Sociological Context, 1(1), 13-26.

MLA:

Bozlu, Birtan. “Pierre Bourdieu Sosyolojisi ve Spor Alanının İnşası.” Sosyolojik Bağlam Dergisi, c. 1, s. 1, 2020, ss. 13-26.

Bozlu, Birtan. "Sociology of Pierre Bourdieu and Construction of Sports Field." Journal of Sociological Context, v. 1, i. 1, 2020, pp. 13-26.

Chicago:

Bozlu, Birtan. “Pierre Bourdieu Sosyolojisi ve Spor Alanının İnşası.” Sosyolojik Bağlam Dergisi 1, s. 1 (2020): 13-26.

Bozlu, Birtan. "Sociology of Pierre Bourdieu and Construction of Sports Field." Journal of Sociological Context 1, i. 1 (2020): 1326. 